\title{
THE EXECUTIVE OFFICE AS ADMINISTRATIVE COORDINATOR
}

\author{
John R. Steelman* and H. Dewayne Kreager $\dagger$
}

The Executive Office of the President is the formal title given to the President's personal staff and personal staff agencies. ${ }^{1}$ Their purpose, of course, is to provide assistance of the most intimate sort to the President in carrying out the responsibilities of his office. Accordingly, the role of the Executive Office is determined by the very nature of the President's job, and, always, by the personality and work habits of the incumbent chief executive.

The President of the United States, in terms of his constitutional powers, plus the accumulation of statutory authority vested in his office by a succession of Congresses, is probably the most powerful single individual in the world today. And when the President succeeds in marshalling the full power of his office, he is virtually irresistible. Every President since the First World War, at one time or another, has exercised the full measure of this power-legal and political. Similarly, no President in that same period has been able to avoid completely the frustration of being unable to bring that full power to bear on occasion in some crucial situation.

The President is two personalities. He is a private individual in his own right who has few opportunities to exercise the privileges of privacy; and a public official of superlative rank who simultaneously wears five executive hats, all of which label him with power and none of which permit him privacy. He is at once the head of the executive branch of the Government, the Commander-in-Chief of the Armed Services, the leader of his political party, the ceremonial head of the State, and his country's decision-making spokesman in the critical do-or-die arena of world politics.

Since the subject of this discussion is the role of the Executive Office in relation-

* A.B. 1922, Henderson Brown College, A.M. 1924, Vanderbilt University; Ph.D. 1928, University of North Carolina. Dr. Steelman was the first to occupy the top White House staff post, The Assistant to the President, which he filled for nearly seven years under President Truman. His Executive Office roles, filled simultaneously with his White House post, have included: Director of the Office of War Mobilization and Reconversion, 1946; Acting Chairman of the National Security Resources Board, 1948-50; and Acting Director of the Office of Defense Mobilization, 1952. Director of the U. S. Conciliation Service, 1937-44. He is now an Industrial Consultant in Washington, D. C., and publisher of a chain of local newspapers in Maryland.

† A.B. 1934, A.M. 1935, State College of Washington; graduate assistant in government, 1935-36, Duke University; Ph.D. 1947, Harvard University. A sixteen-year career public servant, Dr. Kreager served six years in the Executive Office of the President: Executive Secretary of the National Security Resources Board, 1948-50; Executive Officer of the Office of Defense Mobilization and Executive Secretary of the President's National Advisory Board on Mobilization Policy, 1951-53. Since I953, associatcd with Dr. Steelman as a Washington Industrial Consultant.

${ }_{53}$ Stat. $56 \mathrm{r}$ (1939), 5 U. S. C. $\$$ I33-133r, r33t note (1952); Exec. Order No. 8248, Sept. 8, 1939, 3 C. F. R. 576 (Cum. Supp. 1943). The Executive Office includes currently the White House Office, Bureau of the Budget, Council of Economic Advisers, National Security Council (including the Central Intelligence Agency and Operations Coordinating Board), Office of Defense Mobilization, and the President's Advisory Board on Government Organization. 
ship to the President's job as head of the executive branch of the Government, it is important to note that, for all the symbols of power, real and psychological, and for all the tremendous sources of strength which are his to tap within the executive branch of the government and his own official family, his power is generally effective only so long as he does not have to use it.

While a rule of thumb to the effect that a President's authority within his own branch of the government is good only so long as he does not have to use it is not always true, it is of sufficient importance in critical official family situations to serve as a point of departure for this inquiry. Child psychologists who teach psychological persuasion rather than woodshed practicality are Johnny-come-latelys compared to generations of Presidents and presidential assistants who have learned the hard way, that patience and connivance are often better than direct use of the presidential razor strap in dealing with the executive family. ${ }^{2}$ In carrying out the President's job as chief executive, "coordination" is often a much better attitude than "direction." Seldom does the President direct. More often he persuades, sometimes in person, more frequently through his key assistants. Generally, his so-called directives, most of them embodied in Executive Orders, are the product of painstaking weeks of coordinative effort undertaken by his principal staff assistants among his executive subordinates in order to achieve a general meeting of minds before his signature is ever placed upon what in the process has become largely an inoffensive document.

This is not to suggest that knuckles are not sometimes rapped in the process. They are, seldom by the President, but almost always by key assistants who exercise the threat rather than the actuality of presidential power. This leads to the conclusion that there is a considerable amount of art mixed up with the science of running the executive branch of the Government. Effectiveness is much more dependent upon the personal skills of the President and individual top associates than upon forceful application of presidential authority or on the hierarchy of a formal organization chart.

\section{Presidential Authority and Its Limitations}

No President has ever completely avoided the often disastrous reaction against his administration or against him personally as a result of his direct use of executive authority as the boss of the executive branch. Franklin D. Roosevelt's ambivalent settlement of the historic 1943 dispute between Vice President Henry Wallace and Commerce Secretary Jesse Jones, over handling of the Government's wartime procurement programs abroad, is a Washington legend. In that dramatic executive action, Mr. Roosevelt fired the Vice President from his job as Chairman of the Board of Economic Warfare and displaced Secretary Jones as Chairman of the Reconstruction Finance Corporation, a role that put him in charge of the purse

\footnotetext{
"By "executive family" is meant primarily the members of the cabinet and heads of other government agencies, plus key staff members in the White House Office and the agencies of the Executive Office of the President.
} 
strings that controlled the procurement policy programs developed by Wallace's organization. Many of the personal wounds suffered in that battle have never healed. In addition, the administrative headaches resulting from the considerable number of staff resignations in both agencies following the President's action, created an administrative crisis that required months to resolve.

As an administrator, Franklin D. Roosevelt was often criticized for his inability to fire subordinates, for his tendency to solve organizational problems in the executive branch by permitting an existing official or agency to die on the vine while he created a parallel entity to take over the functions thus ignored. Duplications, particularly in the areas of labor, public works, and social welfare, were common in the organizational façade of the Roosevelt administration. Oddly, on closer examination, this "inability" must be counted a real ability on the part of the Depression and Second World War President frequently to resolve problems by ignoring them. This was a subconscious recognition of the basic management principle that little problems become big problems when an important official recognizes them and thereby lends them the importance of his personal prestige.

Many teachers of executive management, efficiency experts of the industrial school, will disapprove the idea of an executive who fails to grasp each problem firmly and forcefully as it arises. In terms of cold statistical efficiency, in the command decision structure of military organization, in the profit-directed practicality of an industrial corporation, or in the pragmatic realism of an authoritarian society, resort to finesse rather than direct action could be a weakness. But the President is neither a statistic nor a box in an organization chart. His effective strength lies in his ability to be human and, above all, in his capacity for being President of all of the people most of the time. Within the framework of American democratic society, with the President standing alone as a man in a fishbowl, with the President's every word and act capable either of supporting or weakening his administration, the techniques of compromise and coordination rather than coercion have special virtues. The very government he commands is founded upon the principles of the right of men to disagree and the achievement of progress through effective compromise. His job is to lead, not to demand. Any public official of importance, the President most of all, must remain persona grata not only to the public, but to his official associates if he is to retain his ability for leadership.

Franklin D. Roosevelt's ability to beat a strategic political retreat on occasion, his willingness to accept a partial program rather than a full program in order to avoid losing an entire objective, represents the master touch in politics. He used the same technique in his relationships with his official executive branch family, a subtle mixture of cajolery, coercion, and coordination, seasoned with overtones from his popular public personality, to keep the gigantic machinery of public administration moving in a desired direction. Some professional management experts and students of public administration may quarrel with FDR's techniques as an administrator, but they cannot deny results in terms of his ability to survive on the 
rough and tumble political scene, or the enormous impact of the programs born in his tenure which are now a permanent part of the structure of American government.

From the administration of President Harry S. Truman, perhaps the best known example of the negative results that can stem from direct use of presidential authority lies in the famous steel industry seizure case of May, r952. That action provided a dramatic and practical example of the difference between the "real" authority and the "legal" authority vested in the President. From the moment the Government took over supervision of the steel industry in order to avoid a strike deemed disastrous to the Korean War effort, there was no question concerning the President's practical authority to take over the steel industry and keep it operating under government jurisdiction. The industry was seized, and it stayed seized until the Supreme Court made a legal determination on June 2, I952, to the effect that the President's act of seizing the industry was unconstitutional. ${ }^{3}$ The President's efforts were a sincere attempt to serve the public interest, and no other President has tried to look more objectively at the public interest or stood more in respect and humility before it. The net loss to the American system of government in this case lies in the fact that it did result in a Supreme Court decision placing a specific limitation upon the powers of the Presidency. The same loss would have resulted had the Court's decision been to support the President's action, thereby giving the imprimatur of the Supreme Court to unlimited coercive action by a future President.

Within the framework of the rigid structure of American government, with elected public officials serving definite and limited terms of office, the ability to respond effectively to national need and public demand (the two cannot always be the same) frequently rests only in the flexible powers of the Presidency. When national emergency demands action and there is no precedent to follow, only the President can move quickly to avoid crisis. In a practical sense, the power of the President to act in the national interest is limited only by the extent of action that public opinion permits him to take. Frequently the technique used, rather than the action taken, is the controlling factor on public opinion. Were we to build up a body of court decisions that specifically restrict the powers of the President to act in time of emergency, the value of flexible leadership vested in the office could be lost, with a corresponding real danger to the survival of the American system of goverment.

President Eisenhower and his new team also learned, and bitterly, the embarrassment inherent in direct exercise of executive authority in the process of the now famous Dixon-Yates case. When the President permitted himself to become personally identified with the decision to award the Government's contract for power needs to the Dixon-Yates combination, the matter became a national issue. Here was a relatively routine problem which achieved major status because it became identified with an important-the most important-public official. It can be demonstrated that this use of presidential authority actually cost the Republican Party

${ }^{3}$ Youngstown Sheet and Tube Co. v. Sawyer, 343 U. S. 579 (I952). 
control of the Senate in the Eighty-fourth Congress. In the months preceding the I954 congressional elections, neither side had been able to make an issue of the public power question. Suddenly, the President's Dixon-Yates decision dramatized the struggle between the public and private power forces. What had been an absent issue became very much present when accorded the white heat of publicity attendant upon its personal identification with the President. It is reasonable to conclude that reaction to the Dixon-Yates decision influenced enough votes in power-conscious Oregon to swing the narrow margin in favor of the Democratic candidate.

Old experienced hands, with years of seasoning behind them in the White House or in the Executive Office of the President, were astonished at President Eisenhower's direct participation in the Dixon-Yates case. It was not the decision itself that was so unusual, but the fact that the President's administrative team had caused or permitted him to become identified personally with the matter. It could be argued that given a few months more time, the administration would have been able to effect sufficient new appointments to both the Atomic Energy Commission and the Board of the Tennessee Valley Authority to arrange for the desired decision to be taken at that lower level without directly involving the President. Here is another classic example of a case in which full use of the President's personal executive powers defeated rather than achieved a basic objective of an administration. It was not the nature of the decision that was so important, but the mere fact that it was the President who made it.

The above examples, drawn from the last three administrations, cannot be said to deny the effectiveness of direct use of the President's management authority within the executive branch in all situations, but they, and many others like them, have created the atmosphere within which the staff of the Executive Office of the President works. Necessarily, the staff acquires an acute awareness of the extreme vulnerability to public opinion of both the President and his office. A protective attitude toward both is the inevitable result. Staffs seek to effectuate management decisions, whenever possible, at levels short of the President himself. This technique has the double advantage of keeping him out of controversial situations and also reducing demands upon his time. When actual use of the President's personal authority becomes unavoidable, the objective is to make every effort to insure that his signature is placed only on documents that represent completed staff work, implying that areas of potential conflict have been resolved.

The staff job of the Executive Office agencies, while largely one of coordination between the office of the Presidency and the key officials of the executive departments and agencies who are his subordinates, also frequently involves a careful sounding of: public or political reaction in advance of presidential action. But the objectives of this study are limited to the management of the executive branch and do not include the political or public relations aspects of his office.

\section{Organization Differences in the Executive Office}

Technically, as a brief glance at the appropriate pages in any recent Con- 
gressional Directory will show, ${ }^{4}$ the Executive Office of the President includes everything and everyone attached to the Presidency other than the President himself and his Army, Navy, and Air Force Aides. ${ }^{5}$ Thus, the White House Office per se is a part of the Executive Office. In practice, however, official Washington-the Congress, the executive departments and agencies, the press-draws a rather clear line of distinction between the White House Office and the rest of the agencies that comprise the Executive Office. While organizational fact does not make such a distinction, operational practice has led to an unofficial reality in which there are essentially two recognized organization entities serving the President: the White House staff and the Executive Office of the President.

Traditionally, the agencies of the Executive Office-for example, the current Bureau of the Budget, Office of Defense Mobilization, and Council of Economic Advisers, and several now nonexistent agencies ${ }^{6}$ have each had a single head. This single-executive organizational structure, providing one official through whom communications are maintained with the President, lends itself to the "agency concept" of such bodies. Such organization stands in contrast with the traditional structure of the White House Office, within which each key member has functioned normally on an informal basis of direct relationship with the President. This character of relationship within the White House Office and the Executive Office was common to both the Roosevelt and Truman administrations. Senior status accrued to certain individuals whose higher rank was generally recognized, but for all intents and purposes, the White House Office functioned as a group of senior staff assistants who had direct access to, and operated directly through, the person of the President himself.

The Eisenhower administration, through conversion of the top White House position, The Assistant to the President, ${ }^{7}$ to that of a chief of staff, has brought about more of an "agency" status to the White House Office than has characterized that body in the past. In any organization, public or private, the group closest to the top executive evolves in a schematic pattern that most fits the wishes and past administrative experience of the man at the top. President Eisenhower's military background undoubtedly accounts for the creation of the chief of staff approach to operation of the White House Office. Whether this change in organization continues in the future depends entirely, of course, upon the preferences and the personality of the next incumbent of the Presidency.

The difference between the White House Office and the Executive Office of

- For instance, Congressional Directory 379-83 (1956).

- The White House Residence staff is not included.

'Among the no-longer-existing agencies: National Security Resources Board, National Resources Planning Board, Office of the Director for Mutual Security, and the Office for Emergency Management.

"The position of "The Assistant to the President" came into being formally under President Truman and was occupied throughout his terms of office by Dr. John R. Steelman. Essentially, the position is the outgrowth of assignments made to the succession of Directors of the Office of War Mobilization, later the Office of War Mobilization and Reconversion, James F. Byrnes, Fred Vinson, John W. Snyder, and John R. Steelman. 
the President assumes some degree of geographical confirmation in the sense that their offices are physically separated. During the Truman administration, the old State-War-Navy Building, directly across West Executive Avenue from the west wing of the White House, was renamed the Executive Office Building and taken over to house the Executive Office agencies. Actually, several members of the White House Office are located in the latter building, but the assumption within Washington bureaucracy is that such officials are "camping out" simply because there is not enough room to provide them with suitable offices in either the west or the east wings of the White House itself. ${ }^{8}$

The President's White House Office staff-The Assistant to the President, his chief counsel, his appointments, press and correspondence secretaries, his legislattve aide, the cabinet secretary, the six anonymous administrative assistants to the President, and other high ranking special assistants-is identified both with the President as an individual and with the office of the President as an organizational entity. With infrequent exceptions, it is from this staff that key officials are selected to accompany the President on his travels, both business and vacation. When members of the White House staff speak publicly, they do so only as spokesmen for the President, not in terms of their personal positions. Veteran members of the White House press corps recognize this close association with the person of the President and generally accord members of the White House Office immunity from direct quotation in the press. The fact of the White House Office staff as a part of the Presidency receives its highest recognition in the traditional treatment accorded it by the Congress, which seldom seeks to require members of the President's staff to testify before congressional committees. Exceptions to this rule are rare.

In contrast, the personnel of the other agencies of the Executive Office of the President are regarded as staff to the office of the Presidency rather than to the President personally. This comparison draws a rather fine line, for, as in all organizations, there are key members of the Executive Office organization who, by virtue of their competence and their personable qualities in the President's opinion, achieve a more personal relationship. However, if we are to explore effectively the role of the Executive Office as a coordinating medium in the operation of the executive branch of the government, this impersonal characteristic must be seen and understood. Members of the staffs of agencies in the Executive Office do testify frequently before congressional committees in terms of their official positions, and in so doing, they are not regarded as committing the President. They make speeches in their own right. They are often quoted directly in the press and, in fact, operate their own press relations staffs apart from the White House press office to handle official news releases relating to operations of their agencies. Heads of Executive Office agencies function much as do heads of major government departments or

\footnotetext{
${ }^{8}$ For example, W. Averell Harriman, while Special Assistant to President Truman in the White House, had his offices in the Executive Office Building in conjunction with his headquarters staff for the Mutual Security Program. Numerous Special Assistants to President Eisenhower have been officed in the Executive Office Building.
} 
independent agencies, except that their actions, within the executive branch, are manifestations supporting or stemming from the authority of the office of the Presidency. From time to time the President may see fit to delegate actual executive authority over segments of the executive branch to the head of an Executive Office agency. Such was the case in the creation of the Office of Defense Mobilization at the time of the Korean War. But the complete control of the President over the proffer or withdrawal of such authority is never in doubt. ${ }^{9}$

Congressional inroads on the President's right to absolute control over the appointment of his key staff assistants is the object of frequent expert criticism. ${ }^{10}$ Within his White House Office staff, this right has never been questioned. Appointments are made independently of any senatorial approval. Within the Executive Office, the reverse is frequently true, for there the heads of staff agencies, albeit part of the President's official staff organization, are sometimes subjected to senatorial approval, ${ }_{a}^{11}$ a factor which diminishes the finality of the President's authority over such subordinates.

Another important difference is the matter of tenure of office in the White House as contrasted to the Executive Office. Invariably, the top White House staff leaves when the President goes out of office, most often as of the date of the inauguration of a new administration, and never later than the period necessary to "assist in the transition of one administration to the other." While it is customary for heads of other Executive Office agencies to submit resignations to coincide with the termination of a presidential term of office, these resignations are not always accepted. Actually, key members of the staffs of Executive Office agencies, other than the White House Office, tend to stay on. ${ }^{12}$ This is a most important factor in the continuity of government and is a principal ingredient in the growing strength and prestige that has accrued to Executive Office agencies over the years. It is true that staff mortality was exceedingly high in the Council of Economic Advisers after January 20, 1953, but this situation did not apply in the Bureau of the Budget, the Office of Defense Mobilization, or the National Security Council. For the most part, within the Executive Office, the continuity of interagency coordination, in terms of permanency

${ }^{\circ} \mathrm{A}$ notable exception to direct presidential authority over the head of an Executive Office agency, and, for that reason, a direct intervention by the Congress in presidential prerogatives, is the statutory grant of authority to the Director of the Bureau of the Budget regarding quarterly allocations to the departments and agencies of annual appropriations. See Budget and Accounting Procedures Act, r950, ${ }_{64}$ STAT. 765 (1950), 3т U. S. C. $\$ 665$ (1952). While a confirmation by the Congress of a previous Executive Order, the statutory enactment does now prevent the President from altering the assignment.

${ }^{10}$ Notably the Commission on Organization of the Executive Branch of the Government (Hoover Commission). See the Report entitled "General Management of the Executive Branch," Feb. 1949, Recommendation No. 3: "The President should not be prevented by statute from reorganizing the President's Office and from transferring functions and personnel from one part of it to another"; and Recommendation No. 4: "The head of each staff agency in the President's Office should be appointed by the President without confirmation by the Senate except the Civil Service Commission." Id. at I5-i6.

${ }^{11}$ The Director of the Office of Defense Mobilization requires senatorial approval. $6_{4}$ STat. 816 (1950), as amended, 65 Stat. I39 (1951), 50 U. S. C. App. \$2153(b) (1952).

${ }_{12}$ For example, James S. Lay, Jr., has been Executive Secretary of the National Security Council under both the Truman and Eisenhower administrations. This continuity is also true for several of the Assistant Directors in the Bureau of the Budget and the Office of Defense Mobilization. 
of tenure for key Executive Office personnel, continued through the shift from the Truman to the Eisenhower administration. However, under the military staff concept of the Eisenhower administration, the Executive Office agencies do not play as weighty a role in the operation of the executive branch as under the Truman administration. Nevertheless, the expert knowledge and experience of staff are still there to be tapped as needed.

\section{History of the Executive OfFice}

Historically, the Executive Office of the President as a formal organization dates only from September 1939. ${ }^{13}$ Like most formal organizations, rather than being created, it evolved. This evolution grew out of the growing demands upon the job of the Presidency, the incredible pyramiding of responsibility of the chief executive in a modern industrial world in which all aspects of government are constantly reaching more and more into the lives of individual citizens and further and further afield into the international political arena. Meanwhile, until 1939, the "executive suite" at r60o Pennsylvania Avenue, had not been enlarged to cope with these growing responsibilities.

The first serious consideration, in modern times, of the problems of managing the executive branch came in I92I from the discussions that resulted in the Budget and Accounting Act of that year. ${ }^{14}$ The great concern at the time was the growing complexity of the Government's fiscal management problems, a direct result of expansion in the scope and nature of American government occurring during the First World War. The rg2I act made two significant contributions to better management: it created the General Accounting Office, as an agency of the Congress, to do a post-audit function for the Congress in checking on the performance of the executive branch, a role never truly filled by that agency; and it set up within the Department of the Treasury a Bureau of the Budget, with a Director appointed by and responsible to the President, whose primary function was that of assembling and codifying the annual budget requests of the many separate agencies so that the President, as chief executive, could present to the Congress a single administrative budget. Obviously, the primary concern of the Congress in the I92I act was its own convenience, the President's office, per se, receiving little actual attention.

The new budget office in the Treasury was a move in the right direction, for in the process of providing convenience to the Congress through the submission of a single coordinated budget, it also provided (not by design) the President with a management arm through which he could take an advanced and detailed look at what his ambitious cabinet subordinates were planning to do. But the difference in governmental tempo between I92x and 1939, at which time the Executive Office was actually created, requires some understanding. The memory of a Washington elder statesman, long prominent in the art and science of public management, helps us in this regard. He recalls an afternoon spent at the White House on a social call to

\footnotetext{
${ }^{13}$ Reorganization Plan No. I of 1939, 53 STAT. 56r (1939), 5 U. S. C. $\$ \$ 133$, 133r, r33t note (1952), Exec. Order No. 8248, 3 C. F. R. 576 (Cum. Supp. I943).

14 Budget and Accounting Act of I92I, 42 StAT. 20 (I92I), 3I U. S. C. $\$ \$$ II-I6 (1952).
} 
President Coolidge in the latter's second term, when the only official business transacted was for the President to select from a group of recent photographs of his person those he wanted printed. By the late thirties, President Roosevelt's New Deal, the war against depression, had so magnified the complexities of executive management that the President simply did not have time to do many of the important tasks expected of him. Prior to 1939, the growing demands of the White House for additional personnel had been met largely through the ruse of borrowing personnel from the executive departments, which were required to keep such loaned personnel on their own payrolls. A notable example was the post of Under Secretary of the Interior, which, by custom, had come to be regarded as the position held by the man who actually filled the full-time role of the President's chief liaison officer with the Congress.

The quiet afternoon example cited above from the days of the Coolidge administration notwithstanding, the complaints of Presidents over the excessive burdens of their office are not limited to the post-Second World War era. ${ }^{15}$ Two factors combined during the depression years to concentrate attention on the organization of the President's own office. First, the complex social and economic programs of the New Deal, which created many new programs and new agencies, with a consequent increase in the number of officials reporting directly to the President. Second, the depression, which simultaneously decreased employment opportunities in private industry and established the federal government as the nation's principal employer, brought into government ranks many experienced managers from private business. How best to manage the then dominant executive branch became a favorite Washington luncheon and dinner conversation topic.

Late in his first term of office, President Franklin D. Roosevelt appointed a President's Committee on Administrative Management to make a study and to report to him on the organizational changes required to provide for more effective coordination and direction of the executive branch. The resulting report, ${ }^{16}$ submitted

${ }^{15}$ See President Franklin D. Roosevelt's letter of Jan. 12, 1937, transmitting to Congress the Report of the President's Committee on Administrative Management: "I am not the first President to report to the Congress that antiquated machinery stands in the way of effective administration and of adequate control by the Congress. Theodore Roosevelt, William H. Taft, Woodrow Wilson, and Herbert Hoover made repeated but not wholly successful efforts to deal with the problem." And ". . . they say, what has been common knowledge for 20 years, that the President cannot adequately handle his responsibilities; that he is overworked; that it is humanly impossible, under the system which we have, for him to carry out his constitutional duty as Chief Executive, because he is overwhelmed with minor details and needless contacts arising directly from the bad organization and equipment of the Government. I can testify to this. With my predecessors who have said the same thing over and over again, I plead guilty." Report of the President's Committee on Administrative Management [hereinafter cited Brownlow Report] iii, iv (1937).

${ }^{20}$ Brownlow REPoRT, op. cit. stupra note 15. Members of the Committee were: Louis Brownlow, Chairman, Charles E. Merriam, and Luther Gulick. The Report was submitted to the President on Jan. 8, 1937, transmitted to the Congress five days later, but required nearly two years for fruition of its principal recommendations regarding reorganization of the President's office, through the medium of the Reorganization Plan No. I of 1939.

See also Somers, The President as Administrator, 283 Annals 104, I06 (1952): "The Committee's signal contribution was its sharp portrayal of the Presidency as the pivot of federal administration, all other aspects being secondary." 
to the President and the Congress in January 1937, is one of the most remarkable public management documents ever written. Called the "Brownlow Report," after its chairman, Louis J. Brownlow, the document is now out of print, but still serves as a bible on administrative management in schools of public administration. Less extensive in its coverage, and now less well known than the more current and equally outstanding reports of the first Hoover Commission, ${ }^{17}$ beginning in 1949 , the Brownlow study limited its attention to the so-called administrative management facets of the government-specifically: personnel, fiscal, and planning.

A direct result of the Brownlow study was the creation of the Executive Office of the President, providing, for the first time, a comprehensive organizational framework within which staff could be provided on a flexible basis to augment the growing demands of the President's job. At the outset, the Office included the Bureau of the Budget by transfer from the Treasury Department, the National Resources Planning Board, and an enlarged White House staff. Also, at this time, 1939, the six Administrative Assistants to the President positions were created, ${ }^{18}$ to be filled, as FDR liked to phrase it, "by young men of great competence with a passion for anonymity." Time has proven that actual anonymity in the White House staff is a rare virtue, but the value of this additional and continuing staff assistance to the President has been proven again and again in the seventeen years these posts have been in existence. Less prominent today than during the Roosevelt and Truman administrations, the six Administrative Assistants to the President have tended to become submerged in what has become the largest White House staff ever assembled. While filled from time to time by professionals with specialized assignments, ${ }^{10}$ for the most part, the "anonymity boys" have been general staff men who filled a variety of assignments as the President's problems demanded. Specialization in these posts has tended to follow a grouping of responsibilities for relationships with certain areas of governmental programs rather than in terms of the pre-service technical specialty of the appointee himself.

\section{The Increasing Size of the White House Office}

The growth in size of the White House Office between the Truman and the Eisenhower administration presents a remarkable example of how the organization around the President tends to evolve haphazardly out of need rather than in accordance with any predetermined plan. In March 1951, at the peak of the Korean War emergency, the Congressional Directory listed only fourteen names and positions deemed to be of sufficient prominence in the White House Office to have such publication. ${ }^{20}$ The latest Directory, January 1956 , lists no less than thirty-nine, almost

\footnotetext{
${ }^{27}$ Reference is here made to the Reports of the First Commission on Reorganizatton of the Executtue Branch of the Government (I949).

${ }^{18}$ The idea for the six Administrative Assistants to the President stems from the Brownzow Report, op. cit. supra note $\mathrm{r}_{5}$, at 5 .

${ }^{20}$ For example, Gabriel Hauge, economic adviser to President Eisenhower, currently fills one of the Administrative Assistant positions.

${ }^{20}$ Congressional Directory, Mar. r95I, pp. 337-38.
} 
three times the Truman total..$^{21}$ Other than his regular staff, in 195I President Truman had only one Special Assistant, W. Averell Harriman, who, in addition to his responsibilities as head of the mutual security program, also served the President as a Special Assistant over a broad range of foreign economic matters.

There are now seven Special Assistants to the President. ${ }^{22}$ This is an item of fundamental importance in Executive Office organization, for appointments of this rank invariably result from gaps in the cabinet approach to administration which require creation of super-administrators who can operate for the President at a level that involves the normal responsibilities of two or more of the heads of the regular departments or agencies. The conclusion is rather obvious-the size of the White House and Executive Office staffs and, above all, the rank of White House staff members, grows in direct relationship to the inability of the more rigid cabinet system to meet growing complexities in the management of governmental programs. The White House staff now comes closer to governing the country than ever before.

While the Eisenhower administration has more presidential attachés of super rank than ever before, and while they seem to stay in their positions longer, perhaps the most powerful Executive Office post was the creation of President Truman. This was the appointment of a Director of Defense Mobilization, as head of the Office of Defense Mobilization, a temporary emergency action in December I950, resulting from the need for an immediate presidential deputy of cabinet rank to control, for the President, the many departments and agencies involved in the Korean mobilization effort. ${ }^{23}$ The position continues, but the nature of the job has changed, as we shall note later. Meantime, the Director of Defense Mobilization is not a member of the White House staff. He is an agency executive in his own right and heads a separate organization within the framework of the Executive Office of the President. His direct staff relationship to the President notwithstanding, the Director of Defense Mobilization is not regarded in Washington governmental folklore as being "White House." The Congress and the press treat him much as they would the head of any other independent governmental department or agency.

The rapid growth of the White House staff under President Eisenhower is particularly interesting because it has resulted in contradiction of a pre-inauguration commitment to return to constitutional cabinet government and eliminate the coterie around the President. ${ }^{24}$ Perhaps no administration has ever come into office with a greater consciousness of management in all of its scientific ramifications. The command-decision military background of the President, with its undertones of general staff organization, combined with the "executive suite" background of many of the key officials in a businessman's administration, make this possible. There is little question but that the administration was sincere in its intention to make govern-

${ }^{31}$ Id,. Jan. r956, pp. 379-8I.

${ }^{23}$ Exec. Order No. Ior93, 3 C. F. R. 156 (1950 Supp.).

"See Robert J. Donovan, Eisenhower: The Inside Story 65 (1956): "President Eisenhower applies greater formality of procedure in the Cabinet than has been adhered to in the past." Actually, Donovan's book devotes very little attention to the internal operations of the staff around the President. 
ment more efficient by emphasizing a return to autonomous cabinet executives and eliminating the White House gang. It is to their credit, perhaps, that a few years in office have taught them that this cannot be done. The end result has been the appointment of super-executives at the White House level, of adequate prestige personally and position officially to permit them to intervene authoritatively in matters involving even members of the cabinet.

\section{Competition in the Cabinet Structure}

Contrary to the neatly stereotyped symmetrical outlines in the organization of the executive branch of the government contained in high school Civics books, the executive branch is not one big happy family. It never has been such under any President. It is too big, too complex, and too human ever to be anything but a fractious free-for-all. This would seem to be a perfectly normal situation, however, in a democratic society which justly prides itself on the promotion of independent thought and seeks to progress through the processes of compromise. Washington's governmental halls are lined with the ghosts of cabinet officers who have come into office with a determination to create efficiency by cutting down both on personnel and on program, only to depart at the end of their terms leaving a bigger and more complex department than they inherited in the first place. With expenditures for nondefense programs now higher for the federal budget in $1957^{25}$ than ever before, this situation continues under the present administration and seems to prove that the trend to bigger government has no relationship to the political party that happens to be in control of the executive branch.

Cabinet officers have special interests to serve within the framework of bureaucracy itself. Some, like the Secretaries of Agriculture, Labor, Commerce, and Interior have a vast political constituency of their own, inside and outside the Government. Any cabinet officer is at least in part a prisoner of his job. His effectiveness depends not so much upon what he gives his staff as what his staff gives him. The average cabinet official comes to his job with a conception of his relationships that regards his ties to the President as primary, his ties to his department as secondary. Essentially, the natural reaction is to regard himself as a part of the President farmed out to hold jurisdiction over a specific segment of the executive branch. Neither Republicans nor Democrats in cabinet jobs differ in the speed with which this concept is quickly changed. The Secretary becomes most often a pleader for a specific cause.

A minor case illustrates the situation quite well. In 1949, the National Security Resources Board, a part of the Executive Office, had a quarter of a million dollars to allocate to the established departments and agencies for preparation of a comprehensive series of raw material and industrial facility studies that could serve as a basic encyclopedia of statistical data for future mobilization planning projects. Since 1949, a recession period, was also a year in which both the administration and the

${ }^{25}$ For a more detailed discussion, see Kreager, The Federal Budget for 1957, 13 InL. Bus. Rev. 6 (1956). 
Congress were seeking to cut government expenditures, largely, as is usual, through personnel reductions in the executive agencies, a vast amount of interdepartmental competition ensued. For any department, capture of a part of the NSRB funds, small as they were, insured retention of some staff at least until a next and possibly more lenient year. For a study of copper, no less than four agencies, Commerce, the Tariff Commission, and two agencies of the Interior Department, competed. This was a problem for Executive Office adjudication, for cabinet officers, plagued as they are by loyalties to their own departments, are in no position to compromise their interests without losing face among their subordinates. At the same time, intense rivalry resulted between Commerce and Interior as to which should do the six studies related to the steel industry. The result was an Executive Office engineered compromise, now generally regarded as controlling, to the effect that Interior is responsible for steel from the iron mine to the production of pig iron, but once pig metal enters the picture, the Commerce Department takes over. This seems a simple enough problem to the uninitiated, but actually it is a very troublesome one in the internal operation of the executive branch. To assume that the President himself would have the time to resolve such a minor jurisdictional problem, allowing for the time that would be required for him to become thoroughly informed as to both sides of the argument, would be absurd. The settlement was worked out at staff level in the National Security Resources Board, an Executive Office agency.

The solution to such daily operational problems is not as simple as the above brief narrative would suggest. The mere existence of an Executive Office agency is not enough in itself automatically to produce decisions that permit the wheels of administration to move. The decisions are the product of a coordination process in which the prestige of every agency and every official involved is protected, if possible, and the imprimatur of presidential authority is used only as an implied threat hovering in the background of the Executive Office agency's manipulations.

The basic ingredient is system. The NSRB, technically headed by a seven-man cabinet-level board, with a chairman who also served as the full-time head of the agency, was in no position to compromise interagency problems at the Board level. Early experience had proven that a cabinet-level board, like the cabinet itself, is not a medium through which decisions can be made; but it also proved that such a group can serve as an effective medium through which, by careful attention to the niceties of official protocol, an executive close to the President and in the difficult position of calling his shots among his nominal superiors, can maintain good personal and official relationships with those key officials. As is normal in any governmental organization, below the board level the NSRB senior staff formed interagency liaison relationships, based on the principle that a good staff man can keep his boss well advised only if he knows what other bosses of similar level are thinking about, struggling with, and planning or hoping to do. This mutually dependent interagency staff relationship is a common thing, and a healthy thing, for without it, much of the continuity and coordination required to keep a vast governmental 
structure functioning smoothly could not be accomplished. Sometimes it even becomes desirable to formalize, openly, this type of mutually dependent interagency staff relationship. ${ }^{26}$

Logic can be applied to the compromise of a competitive bureaucratic situation when the "face" of the negotiators is not involved. An informal NSRB interdepartmental staff group actually worked out the solution to the competitive struggle over the materials surveys, which put their bosses in the position of accepting a staff recommendation, thereby protecting them from the necessity of making an original policy determination that could prejudice their position in their own organizations. Obviously, even the coordination process requires a focal point or a spearhead. Only the staff of the President (the Executive Office) can provide this, for that staff enjoys the peculiar advantage of operating under the cloak of the boss who is the boss of everybody else's boss. Sometimes heads fall or pressure is applied, but more often the time worn adage of good staff organization prevails-reasonable men, reasonably assembled, can usually reach reasonable solutions to legitimate problems.

While the President's job requires him to tackle daily the world's toughest management assignment, the very nature of his responsibility demands that he provide broad positive leadership toward over-all national objectives. Before he can make a policy decision, he must have adequate and continuing information covering all major facets of the situation facing him. Cabinet members and agency heads, by virtue of their specific and limited responsibilities, cannot make these broad determinations. It is from the cabinet and agency heads that the President must expect to receive the varied and often conflicting recommendations which need to be carefully sifted and balanced off against the administration's national or international objectives before a decision can be made. No board (e.g., cabinet in this case) can make decisions in the face of intramembership conflicts of jurisdiction, when the man in the chair controls the board rather than the board controlling the chair. It is naive to assume otherwise.

Then who does the sifting? There are occasions in which a cabinet officer can perform this task. For example, President Truman assigned to Secretary of Commerce Charles Sawyer the task of being the administration spokesman on the St. Lawrence waterway project, and the Secretary and his staff to a large extent did the sifting on interagency relationships to that assignment. But most of the time, the sifting is done for the President within the framework of his own White House Staff or Executive Office.

The President needs advice and guidance on matters of national policy from every possible angle of public importance. His staff normally is organized to do this. There is always at least one, generally the Director of the Bureau of the Budget, who must look at a proposal with the cold hard facts of cost constantly before him. It is not his job to judge political implications or impact upon foreign or domestic policy. Another, currently the Director of Defense Mobilization, should be concerned not

\footnotetext{
${ }^{20}$ The interagency senior staff of the National Security Council is a good examplc.
} 
at all with cost, but always with the implications for national security, economic and military, uppermost in his mind. A third source, the National Security Council, may be equally concerned with national security but primarily from the approach that thinks in terms of the hard statistical facts of military supremacy rather than the more elusive factors of domestic economic well-being. The latter is the province of the Council of Economic Advisers. Another may look at a policy proposal from the standpoint of impact on government organization. Ofttimes, the President is his own political adviser, but he may call in his political party national chairman to help weigh the political implications inherent in a variety of possible decisions and their probable impact on the voting public in a forthcoming election. More often than not, personality factors within the executive family itself have to be considered. Any decision a President might make involving jurisdictional assignments in the management of natural resources, for example, would be sure to please and displease simultaneously one or more of the Secretaries of Agriculture, Interior, and Commerce, and possibly several of the regulatory agencies. A too-quick decision by a President can make a cabinet position untenable to an incumbent, and a resignation might follow, creating embarrassment to the administration. If anyone, anywhere, knows that it is impossible to please everyone all the time, even within the official executive family of the United States Government, it is the President.

Sometimes the sifters themselves have to be sifted, and the Assistant to the President or the President's chief counsel frequently fills this role. Other times, the President may call in a personal friend for unofficial advice on a particular problem. At times, special presidential advisory boards, complete with official certificates of presidential appointment, may be set up on a continuing basis to provide a forum wherein policy problems can be worked over from all angles, not for decision purposes, but just to insure that no significant aspect is overlooked. President Truman created his National Advisory Board on Mobilization Policy, a highly controversıl bipartisan body composed of labor, industry, agriculture, and "public" members, just for this purpose. ${ }^{27}$ President Eisenhower has made even more frequent use of the public-advisory-board technique to keep the sifting process a little farther away from the President's office and to insure more comprehensive consideration of all possible angles of public interest. Such presidential advisory boards are serviced, staff-wise, from the ranks of the Executive Office agencies.

Sometimes temporary Executive Office agencies are created to provide an intervening level for settlement of disputes, to keep such adjudication processes away from the President and his chief assistants, or at least to hold them up long enough to permit resolution of the problem at a higher level. At the time the Office of Defense Mobilization was created, to which was assigned jurisdiction over both the emergency production control and emergency stabilization control programs, the Economic Stabilization Agency was used for this specific purpose. It provided an intermediate level between the Office of Price Stabilization and the Wage Stabiliza-

${ }^{27}$ Exec. Order No. 10224, 3 C. F. R. 418 (1951 Supp.) 
tion Board, on the one hand, and the President and the Director of Defense Mobilization on the other. As a result, appeals from decisions of the wage and price operating agencies were handled by the Economic Stabilizer, and only appeals from his decisions were allowed to crowd the time of the Defense Mobilizer. Thus, the President became involved only as a final court of appeal on issues of outstanding importance.

But no one, absolutely no one but the President himself, can make the final decision on matters of basic policy, either as to substance or organization structure. In the current enthusiasm for relieving the President of some of the burdens of his office, this fact is too often overlooked. It would be wrong to imply that any degree of effectiveness in the organization and functioning of the President's staff could free him from the tasks of the ultimate responsibility vested in his office. Any decision made by a subordinate in the executive branch, even under the clearest possible delegation of authority from the President, is always subject to appeal and review by the President if it goes awry. His staff can only assist him in approaching the problem; they cannot remove from his shoulders the weight of his final responsibility.

\section{The Office of Defense Mobilization}

The evolution of the powers and authority of the Director of Defense Mobilization offers a case example of how the Executive Office structure permits flexibility to meet an administrative need. In December 1950, when President Truman signed the Executive Order creating the Office of Defense Mobilization, he handed to the new Director, Charles E. Wilson, ${ }^{28}$ the broadest grant of power ever held by anyone other than the President himself. ${ }^{29}$ Possibly no other legal act of either the Congress or the President ever came so close to the actual creation of an Assistant President. Mr. Wilson held in his hands the authority that literally gave him jurisdiction over the entire enomomy of the nation, subject only to the President's power of approval or right to withdraw the grant of authority.

Existence of such broad overriding operational authority within the person of an agency head in the Executive Office of the President violates the tradition that the Executive Office coordinates rather than commands. However, the fact that this can be done in an emergency suggests the convenience that the Executive Office structure lends to a President when necessity demands that he delegate some of his problems and authority and finds himself in a position where the inter-departmental nature of such problems makes it impractical to delegate them to a single cabinet head. Unfortunately, the appearance of a "czar" in the midst of the President's own staff agencies does create problems of conflict among his own staff. As a result, White House staff members may find themselves acting as a buffer between the President and a "czar" on his own staff. As a matter of practice, however, delegation

${ }^{28}$ The reference is to Charles Edward Wilson, at the time President of the General Electric Company, and the former Executive Vice-Chairman of the War Production Board during World War II.

${ }^{29}$ Exec. Order No. 10193, 3 C. F. R. 156 (1950 Supp.). Based on authority granted the President under the Defense Production Act of 1950, 64 STAT. 798 (1950), 50 U. S. C. App. $\$ \$ 2061-66$ (1952). 
of overriding operational authority, openly and without reservation other than appeal to the President himself, is a temporary expedient used only in periods of emergency.

The justification for the unusual delegation of authority to the Defense Mobilizer grew out of compounding emergency problems: a hot war in Korea that threatened to become hotter, the realization that the United States had become committed indefinitely to world leadership in a long cold-war against the spread of Communism, and the hard fact that the economy of the country had to be rebuilt on a mobilization basis that would permit this democracy to exist on a semiwar footing for an indefinite period of years. Serious shortages in critical and strategic raw materials, actual inadequacies in vast areas of industrial production facilities, imbalances in the nation's economic system that required governmental imposition of direct and indirect stablization controls, lags in production of military end items, all combined to emphasize the temporary need for a mobilization "czar" who could move rapidly and decisively to redirect the country's production machinery and, at the same time, handle the inevitable organizational conflicts that would result in the bureaucratic structure of the government itself.

On March 3r, 1952, when Mr. Wilson resigned and returned to private life, sufficient improvement in the critical economic problems related to the mobilization effort had been achieved to permit some relaxation in the dominant role of the Office of Defense Mobilization. In the late spring and summer of 1952, the Assistant to the President, Dr. John R. Steelman, doubled in brass as Acting Mobilizer during a time in which emphasis began to shift from a build-up of controls to the development of an orderly approach to the removal of controls. This process was continued during the final months of the Truman administration by Mobilizer Henry $\mathrm{H}$. Fowler and reached actual decontrol in many items in the spring of r 953 after the Republicans came in.

The present director of Defense Mobilization, Arthur S. Flemming, who took over after inauguration day, has completed the transition of ODM from an operating command agency to a staff agency. Dr. Flemming has conceived his role as Defense Mobilizer as being that of the President's chief staff assistant for the coordination of the mobilization activities of the various departments and agencies, an approach that fits neatly into the current administration's general staff ideas for running the President's Office. The transition from a super-agency, with powers to direct and control, to a staff agency functioning in the medium of coordination was completed in April 1953, when the operating production agency, Defense Production Administration, and the permanent planning agency, the National Security Resources Board, were consolidated into the Office of Defense Mobilization, which became a permanent entity within the framework of the Executive Office of the President. ${ }^{30}$

ODM retains certain important policy authority within the economic mobilization

\footnotetext{
${ }^{30}$ Reorganization Plan No. 3 of 1953,63 StaT. 203, 5 U. S. C. $\S 1332$ (1952). 3 C. F. R. 134 (1953 Supp.).
} 
sphere, but it now operates primarily to codify and coordinate the recommendations and determinations of the departments most involved in the operation of the mobilization program, principally the Departments of Defense, Commerce, and Interior. While there are those who would like a more aggressive point of mobilization control short of the President, the transition of this Executive Office agency from a command to a staff role has been a normal process, resulting from the constant procedure of adjusting organization to public need. In this process, changes have been influenced probably very little by the politics inherent in the shift from the administration of one major party to that of the other.

A major organizational problem in post-war mobilization, starting with the original National Security Resources Board in 1947 and running through to the present Office of Defense Mobilization, has been the complication of mixing the cabinet into the functions of the President's own Executive Office staff. In creating the National Security Resources Board, the Congress provided for the appointment, by the President, of a board per se. This has been a cabinet-level board from the beginning. ${ }^{31}$ The mixing of cabinet members, semiautonomous heads of executive departments in their own right, and advisers to the President in their specialized areas of responsibility, into the operation of an Executive Office agency has worked badly from the start. The original Board, including in its membership some cabinet members of great experience in actual mobilization operations during the Second World War, ${ }^{32}$ moved to intervene in the operation of the Board's staff organization from the beginning. They were resisted by both the President and his staff. The President's position prevailed, and the Board per se, later transferred intact as the Defense Mobilization Board after the creation of the Office of Defense Mobilization, became, primarily, an informal high-level medium through which the Chairman (NSRB) or the Director (ODM) could maintain effective liaison with top government officials, who enjoyed, for the most part, closer official relationships with the President than they did. Under Truman, this cabinet-level Board, superimposed on an Executive Office agency created in large part to coordinate cabinet officers, never became a decision making body. From time to time it made recommendations to the President, but the latter always made his own decisions.

Under Eisenhower, the position of the Defense Mobilization Board changed abruptly. Overnight it became an actual, decision making body, if not by charter, then certainly in fact, for a DMB recommendation to the President now invariably receives presidential approval. This intrusion of the cabinet into the functions of what would normally be presidential staff tends to reduce the prestige and effectiveness of

${ }^{31}$ The National Security Resources Board was created under Scc. 103, National Security Act of 1947, 61 Stat. 499 (1947), as amended, 64 Stat. 1280 (1950). 50 U. S. C. App. $\$ 404$ (1952). Regular membership on the National Security Resources Board, per se, and its successor, the Defense Mobilization Board, has included the Sccretaries of State, Treasury, Defense, Interior, Agriculture, Commerce, Labor, plus the Chairman of the Board of Governors of the Federal Rescryc System.

${ }^{32}$ Particularly Secretary of Defense James Forrestal and Secretary of the Interior Julius Krug, who, as Sccretary of the Navy and War Production Board Chairman, respectively, during World War II, became acknowledged experts in the finer details of mobilization programming. 
the agency as a personal arm of the President and cuts down on the number of effective eyes and ears he has available to help him. The development in respect to the Defense Mobilization Board is a manifestation of the current administration's desire to return governmental power to the cabinet level, a fact not entirely contradicted by the creation of the largest super-staff at the White House level ever assembled. The situation becomes one of a cabinet taking over the President's regular staff, but in turn being superseded on many matters by a super-general staff at the White House level.

\section{The Bureau of the Budget}

The agency whose functions and operations lend themselves best to an understanding of the staff nature of the Executive Office of the President as an adminstrative coordinator is the Bureau of the Budget. As previously noted, it was the transfer of the Bureau from the Treasury to the White House in 1939 that marked the formal beginning of the Executive Office of the President as we know it today. Originally set up to do a budget review and codification job, the Budget Bureau has become, in fact, the chief staff arm of the President in the management of the executive branch. ${ }^{33}$ The budgetary process is the sole medium through which the multitude of governmental activities and program and the agencies they support can be reviewed annually in their entirety and in relationship to a coordinated program for the promotion of the welfare and security of the nation and its people. The federal budgetary process is now said to occupy fifteen months out of each year, a figure of speech used to illustrate the fact that completion of the budget for one given fiscal year often overlaps by several months the beginning of the process for the budget to apply in the ensuing year. With federal expenditures now a major sustaining factor in the economy of the nation, and a basic ingredient in the management of the economy of the country, the budget becomes a key factor in the determination of all fiscal policies. Broad policy or program statements in even such important documents as the President's State of the Union Message or Economic Message are one thing, but the dollars and cents figures in the budget are another as far as proving the actual extent to which such statements of policy may see realization in practice.

Since the presentation of the budget requires detailed examination into the programs and organization of every government department and agency, the Bureau has acquired important management and organization staff functions. Through its statistical standards staff, it exerts control over the assignment and natlire of the multitude of publications issued by federal agencies, and reduces duplication and conflicts between the agencies as to the content of publications and the staff required to produce them. Through its legislative reference service, it becomes the focal point within the executive branch for the review of bills pending before the

\footnotetext{
${ }^{33}$ The most recent comprehensive treatment of the Bureau of the Budget will be found in ARTHLR Saithies, The Budgetary Process in the United States particularly cc. II, IV, V, VIII, and $\mathrm{X}$ (1955).
} 
Congress and for the assembly and submission of a unified administration position on such bills. This little-publicized feature of the Bureau of the Budget is perhaps the single most important ingredient in a unified approach by the executive branch agencies to matters pending before the legislature. Without it, the President would be hard put to keep up with the ideas generated by the hierarchy he normally is supposed to command.

The greatest asset to the Bureau of the Budget, however, has been its personnel. Over the years, it has acquired an unusually competent staff of specialists who represent, in the combination of all their fields of specialization, a comprehensive knowledge of the vast ramifications of the federal government. This continuing competence in the knowledge of day-to-day government operations is available for each succeeding President to tap. Not the least among attractions that have lured able young men into the Bureau is that it offers one of the best stepping stones to advancement in a professional public service career. Many a budget review officer has moved out into a top executive position in one of the agencies he has been handling on a staff budget assignment.

In less than twenty years, the Bureau has become an effective comptrollership operation, not unlike those common to effective management in big private industry. During the Truman administration, the Budget Director had regular daily access to the President and kept him constantly posted on the internal administrative management of the executive branch. Simultaneously, key Budget Bureau staff members worked in staff harness with specialists in the White House office. The relationship was continuous, professional in character, and personally informal.

The end result of the growth of the Bureau of the Budget was that it acquired not only enormous prestige within the ranks of government, but also exerted a vast amount of power-power of the most fundamental sort, control over the availability of funds to develop programs and to employ people. For this reason, its popularity has never paralleled its prestige or its power, but this does not in any way lessen its effectiveness.

\section{ConcLusron}

At the beginning of this inquiry into the role of the Executive Office of the President, a careful distinction was drawn between the status of the White House Office and that of the other Executive Office agencies. The nature of the differences has been further altered by the changes in organizational emphasis between the Truman and Eisenhower administrations. The small Truman White House staff was balanced by a more extensive delegation of responsibility to other Executive Office agencies. At present, the application of the military general staff concept to the structure of the President's White House organization has resulted in a very large White House staff which has tended to remove from the permanent Executive Office agencies some of the influence and effectiveness they previously enjoyed. A case in point is the Bureau of the Budget. Long the dominant point of influence 
in the control over the preparation of expenditure estimates, it actually influenced very little the final budget figures for the federal budget for 1957. The point of control had shifted across the street to the general staff in the White House. Similarly, influence once exercised in the Office of Defense Mobilization has shifted to points of origin in Defense, Commerce, Interior and other agencies. ${ }^{34}$

Space limitations do not permit detailed examination of the role of the National Security Council, itself a coordinating medium for the agencies and officials most involved in national defense on the military and diplomatic fields, or of the Council of Economic Advisers, a staff and advisory agency in the strictest sense.

Even after twenty years of concentrated attention on the organization of the President's office and its staff components and the role of that staff in the management of the executive branch, management technicians have only just begun the study of that tremendously important segment of our public administration structure. So long as Presidents and the public in general are concerned over the excessive burdens imposed upon the occupant of the world's toughest job, so long shall we continue to try to improve the situation by additions and changes in the staff organization that surrounds him. Since Presidents are, after all, human beings, and thus subject to the variations in personality and skills that are usual to all members of the human race, then the most important consideration in organizing the Executive Office or carrying out its mission is to keep it flexible. Flexibility is necessary to adjust to the personality of individual Presidents, to adapt organization to the urgencies of a constant parade of government problems and new public responsibilities, and to insure continuity in staff around the highest point of governmental leadership-which point must arbitrarily be changed from time to time under the dictates of our political system.

The White House Office and the Executive Office, as organizations, do not lend themselves to precision organization planning. If such were true, then only one President in the history of the United States could have been right-and you take your choice. The personality of each President, and the political, economic, and social demands of his term of office, will combine to dictate the structure and character of the group around him that assists him, minute by minute, in carrying out the overwhelming burdens of his office. To date, we must admit, even allowing for continuing faults, that flexibility has prevailed and that organizational structure through all its changes, has at least satisfied the desires, if not the needs, of each President-and who better has the right to determine what his needs shall be?

\footnotetext{
${ }^{34}$ This discussion of the role of the Executive Office of the President has not been intended as an inquiry into the faults or virtues of any particular administration in the operation of the President's own staff organization. Rather, it has been intended as an examination of the organizational climate within which the Executive Office must function, and the demands and motivations that limit or guide its actions-as a unit and as individuals within that unit.
} 